\title{
Occurrence of enterotoxin-encoding genes in Staphylococcus aureus causing mastitis in lactating goats ${ }^{1}$
}

\author{
Daneelly H. Ferreira², Maria das Graças X. Carvalho ${ }^{2 *}$, Maria J. Nardelli², Francisca \\ G.C. Sousa ${ }^{3}$ and Celso J.B. Oliveira ${ }^{3}$
}

\begin{abstract}
Ferreira D.H., Carvalho M.G.X., Nardelli M.J., Sousa F.G.C. \& Oliveira C.J.B. 2014. Occurrence of enterotoxin-encoding genes in Staphylococcus aureus causing mastitis in lactating goats. Pesquisa Veterinária Brasileira 34(7):633-636. Laboratório de Inspeção e Tecnologia de Produtos de Origem Animal, Centro de Saúde e Tecnologia Rural, Universidade Federal de Campina Grande, Patos, PB 58700-000, Brazil. E-mail: mgxc@bol.com.br

Staphylococcal enterotoxins are the leading cause of human food poisoning worldwide. Staphylococcus spp. are the main mastitis-causing agents in goats and frequently found in high counts in goat milk. This study aimed to investigate the occurrence of enterotoxin-encoding genes in Staphylococcus aureus associated with mastitis in lactating goats in Paraiba State, Brazil. Milk samples $(\mathrm{n}=2024)$ were collected from 393 farms. Staphylococcus aureus was isolated in 55 milk samples. Classical (sea, seb, sec, sed, see) and novel (seg, seh, sei) enterotoxin-encoding genes were investigated by means of polymerase chain reaction (PCR). From thirty-six tested isolates, enterotoxin-encoding genes were detected in 7 (19.5\%) S. aureus. The gene encoding enterotoxin C (seC) was identified in six isolates, while seiwas observed in only one isolate. The genes sea, seb, sed, see, seg and seh were not observed amongst the $S$. aureus investigated in this study. In summary, $S$. aureus causing mastitis in goats can harbor enterotoxin-encoding genes and $\mathrm{seC}$ was the most frequent gene observed amongst the investigated isolates. This finding is important for surveillance purposes, since enterotoxin C should be investigated in human staphylococcal food poisoning outbreaks caused by consumption of goat milk and dairy products.
\end{abstract}

INDEX TERMS: Enterotoxin-encoding genes, food poisoning, goat milk, Staphylococcus aureus.

RESUMO.-[Ocorrência de genes codificadores de enterotoxinas em Staphylococcus aureus associados a mastite em cabras em lactação.] As enterotoxinas estafilocócicas são as principais causas de intoxicação alimentar em humanos em todo o mundo. 0 principal agente causador da mastite caprina são os Staphylococcus spp., frequentemente encontrado em altas contagens no leite caprino. Este estudo objetivou investigar a ocorrência de genes codificadores de enterotoxinas em Staphylococus aureus associados com mastite em cabras em lactação no estado da Paraíba, Brasil. As amostras de leite $(n=2024)$ foram coletadas em 393 propriedades. Foram isolados 55

\footnotetext{
${ }^{1}$ Received on January 7, 2014.

Accepted for publication on May 12, 2014.

${ }^{2}$ Inspeção e Tecnologia de Produtos de Origem Animal, Centro de Saúde e Tecnologia Rural (CSTR), Universidade Federal de Campina Grande (UFCG), Patos, PB 58700-000, Brazil. *Corresponding author: mgxc@bol.com.br

${ }^{3}$ Centro de Ciências Agrárias, Centro de Ciências Agrárias (CCA), Universidade Federal da Paraíba (UFPB), Areia, PB 58397-000, Brazil.
}

S. aureus em amostras de leite. Os genes codificadores de enterotoxinas clássicas ( $\mathrm{sea}, \mathrm{seb}, \mathrm{sec}$, sed, see) e as novas (seg, seh, sei) foram investigadas por meio de reação em cadeia de polimerase (PCR). Foram testados trinta e seis isolados, foram detectados $7(19,5 \%)$ genes codificadores de enterotoxinas de $S$. aureus. 0 gene codificador da enterotoxina $\mathrm{C}(\mathrm{sec}$ ) foi identificado em seis isolados, enquanto sei foi observado em apenas um isolado. Os genes sea, seb, sed, see, seg e seh não foram observados entre os $S$. aureus investigados neste estudo. Em síntese, a mastite caprina causada por $S$. aureus pode abrigar genes codificadores de enterotoxinas e sec foi o gene mais frequentemente observado entre os isolados investigados. Essa descoberta é importante para fins de vigilância e a enterotoxina C deve ser investigada em surtos de intoxicações alimentares estafilocócicas em humanos causadas pelo consumo de leite caprino e seus derivados.

TERMOS DE INDEXAÇÃO: Genes enterotoxigênicos, intoxicação alimentar, leite caprino, Staphylococcus aureus. 


\section{INTRODUCTION}

The majority of foodborne diseases outbreaks is associated with the consumption of animal-derived products, especially milk and dairy products. It's known that the incidence of human food poisoning in Brazil is related tovarying socioeconomic and cultural factors in each geographical region (Brasil 2010). The Northeast region is amongst the main goat milk producing region in South America. However, the goat milk production chain is comprised mainly by family producers. There is no trading regulations for goat milk and this food is marketed informally mainly in rural areas. This fact poses a public health risk, since the consumption of non-pasteurized goat milk and dairy products elaborated with raw milk are associated with foodborne zoonosis transmission to humans (Rall et al. 2008).

Staphylococcus aureusis amongst the main foodborne pathogen worldwide and itspathogeny is mainly associated with food poisoning triggered by staphylococcal enterotoxins. These enterotoxins are thermal resistant and the majority of foodborne poisoning outbreaks are linked to the consumption the classical enterotoxins (SEA-SEE), even though food poisoning cases attributed to novel enterotoxins (SEG-SEU) have been also reported (Jarraud et al. 1999).

Sanitary problems in the goat milk production chain in Northeastern Brazil might be related to the low microbiological quality the milk yielded by many family producers. Staphylococcus spp. are the main mastitis-causing agents in goats and are frequently found in high numbers in goat milk. Therefore, in view of the potential risk for contamination of goat milk by Staphylococcus organisms, this study aimed to investigate the occurrence of enterotoxin-encoding genes in S. aureus associated with mastitis in lactating goats in Paraiba State, Brazil.

\section{MATERIALS AND METHODS}

\section{Samplings and Staphylococcus isolation}

A total of 2024 milk samples were collected from lactating goats from 393 farms located in two important goat milk producing regions in Paraiba State, Cariri and Sertão. Samplings were performed from March 2010 to November 2011 and included 6 municipalities in Cariri (Amparo, Cacimba de Cima, Juazeirinho, Monteiro, Prata and Sumé) and 8 municipalities in Sertão region (Cacimba de Areia, Café do Vento, Emas, Passagem, Santa Terezinha, São Mamede, São José do Sabugi and Várzea). All sampled farms included in the study took part in the Governmental programs "Fome Zero" and "Leite da Paraíba", by which the milk yielded by the family producers is pasteurized in small-scale dairy plants owned by the association of producers and bought by the Government to be distributed to public children schools and daycare units in Paraiba State.

Milk samples were sampled from each teat individually after disinfection using $70 \%$ ethanol and drying with paper towels. Foremilk was discharged before milk collection and milk was collected using sterile glass tubes and taken to the lab under refrigeration. Aloopful of milk samples was streaked onto Blood agar (Oxoid Ltd, Basingstoke, UK). After incubation for $24 \mathrm{hrs}$ at $37^{\circ} \mathrm{C}$, Staphylococcus was confirmed based on morphology, Gram staining, catalase, oxidase and coagulase tests. Species identification was performed in a semi-automated system (Autoscan $4^{\circledR}$, Siemens Healthcare, USA) using a biochemical-based colorimetric panel (Combo PC33; Siemens). Readings were performed by means of a commercial software for species confirmation (LabPro Connect; Siemens).

\section{DNA extraction and detection of enterotoxin-encoding genes by PCR}

Genomic DNA was extracted by phenol:chloroform:isoamyl alcohol (Sambrook et al.1989). Extracted DNA concentrations on the samples were measured (Biophotometer Plus, Wesseling-Berzdorf, Alemanha) and adjusted at $50 \mathrm{ng} / \mu \mathrm{L}$ to be used as DNA tamplate in the PCR assays.

The polymerase chain reaction for identification of each classical (sea, seb, sec, sed, see) and novel (seg, seh, sei) enterotoxin-encoding gene was performed individually according to the conditions described by Blaiotta et al. (2004) in a $25 \mu \mathrm{L}$ master mix volume containing $0.4 \mu \mathrm{M}$ of each primer, $200 \mu \mathrm{M}$ of each dNTP, $2 \mathrm{mM}$ of $\mathrm{MgCl} 2,100 \mathrm{ng}$ of genomic DNA and $1 \mathrm{U}$ of Taq DNA polymerase (Invitrogen, São Paulo, Brazil). The primer pairsused in the PCR assays and the expected amplicon size for each gene investigated in the present study are shown in Table 1.

Amplification reactions were performed in a thermal cycler (Techne TC5000, England) under the following cycling conditions: initial denaturation at $95^{\circ} \mathrm{C}$ for 3 minutes; 30 amplification cycles

Table 1. Oligonucleotide primers used in the polymerase chain reactions (PCR) to identify classical (sea-see) and novel (seg-sei) enterotoxin-encoding genes in Staphylococcus aureus from goat milk in Paraiba and the expected size of amplicons

\begin{tabular}{|c|c|c|c|}
\hline Primer & Sequence $\left(5^{\prime} \rightarrow 3^{\prime}\right)$ & Fragmentsize (bp) & Reference \\
\hline sea-1 & TTG GAA ACG GTT AAA ACG AA & 120 & Johnson et al. (1991) \\
\hline sea-2 & GAA CCT TCC CAT CAA AAA CA & & \\
\hline$s e b-1$ & TCG CAT CAA ACT GAC AAA CG & 478 & Johnson et al. (1991) \\
\hline$s e b-2$ & GCA GGT ACT CTA TAA GTG CC & & \\
\hline $\sec -1$ & GAC ATA AAA GCT AGG AAT TT & 257 & Johnson et al. (1991) \\
\hline $\sec -2$ & AAA TCG GAT TAA CAT TAT CC & & \\
\hline sed-1 & GTA GTT TGG TAA TAT CTC CT & 317 & Johnson et al. (1991) \\
\hline sed-2 & TAA TGC TAT ATC TTA TAG GG & & \\
\hline see-1 & CAA AGA AAT GCT TTA AGC AAT CTT AGG CCAC & 482 & Jarraud et al. (1999) \\
\hline see-2 & CTT ACC GCC AAA GCTG & & \\
\hline $\operatorname{seg}-1$ & AAT TAT GTG AAT GCT CAA CCC GATC & 642 & Jarraud et al. (1999) \\
\hline $\operatorname{seg}-2$ & AAA CTT ATA TGG AAC AAA AGG TAC TAG TTC & & \\
\hline seh-1 & CAA TCA CAT CAT ATG CGA AAG CAG & 376 & Jarraud et al. (1999) \\
\hline seh-2 & CAT CTA CCС AAA CAT TAG CACC & & \\
\hline sei-1 & CTC AAG GTG ATA TTG GTG TAGG & 577 & Jarraud et al. (1999) \\
\hline sei-2 & AAA AAA CTT ACA GGC AGT CCA TCTC & & \\
\hline
\end{tabular}


comprised by a denaturation step at $95^{\circ} \mathrm{C}$ for 30 seconds, annealing at $55^{\circ} \mathrm{C}$ for 75 seconds and extension at $72^{\circ} \mathrm{C}$ for 30 seconds. A final extension step at $72^{\circ} \mathrm{C}$ for 5 minutes. Amplification reactions included the positive controls: S. aureus ATCC 13565 (sea), S. aureus ATCC 14458 (seb), S. aureus ATCC 19095 (sec, seh and sei), S. aureus ATCC 23235 (sed and seg) and S. aureus ATCC 27664 (see).

The amplification products of PCR reactions were visualized by electrophoresis in a $2 \%$ agarose gel (LGC Biotechnology, Brazil).After staining for 30 minutes with Gelred (Biotium, USA), the presence of amplified fragments was detected visually under UV by means of a transilluminator (Bioagency, São Paulo, Brazil).

\section{RESULTS AND DISCUSSION}

Out of the 2024 collected milk samples, staphylococci organisms were identified in 273 (13.4\%) samples, from which $55(20.1 \%)$ were identified as Staphylococcus aureus. From thirty-six $S$. aureus screened by PCR, enterotoxin-encoding genes were detected in 7 (19.5\%) isolates. The gene encoding enterotoxin $\mathrm{C}(\mathrm{seC})$ was identified in six isolates, while sei was observed in only one isolate. The genes sea, seb, sed, see, seg and seh were not observed amongst the $S$. aureus investigated in this study.

The frequency of enterotoxin-encoding genes in $S$. aureus from goat milk observed in the present study was lower than $65.2 \%$ reported by Scherrer et al. (2004) in $S$. aureus from bulk tank goat milk samples in Switzerland. High frequencies of enterotoxin-encoding genes have been reported in $S$. aureus from bovine origin in studies carried out in Brazil (Nader Filho et al. 2007, Rall et al. 2008) and in France (Rosec \& Gigaud 2002). Information about enterotoxin-encoding genes in Staphylococci from goat milk is scarce in Brazil. However, the frequency of positive isolates found in the present study is very similar to $23.3 \%$ of coagulase-positive staphylococci from bulk tank goat milk in Cariri region harboring at least one enterotoxin-encoding gene (Lyra et al. 2013).

Only two genes were detected in the present study and the majority of the positive isolates (85.7\%) carried seCgene. This has also been reported as the most frequent gene in staphylococcus from goat milk by Scherrer et al. (2004) and Lyra et al. (2013), who observed secin $42 \%$ and $55.6 \%$ of positive staphylococci, respectively. The gene sec was also reported by Loncarevic et al. (2005) as the most frequent classical enterotoxin-encoding gene amongst Staphylococcus from goat milk. The presence of this gene was seen in 71\% (Mork et al. 2010) and 86\% (Silva et al. 2005) of Staphylococcus recovered from healthy goats and goats with udder infections, respectively. Cremonesi et al. (2006) reported that gene sec was detected almost exclusively in staphylococci from goat origin when compared with staphylococci from other animals. Moreover, the frequency of this gene reached $97.3 \%$ of the isolates.

The results of the present study showed only one isolate harboring a novel enterotoxin-encoding gene (sei). Conversely, a higher frequency of novel enterotoxin-encoding genes compared to the classic ones has been reported worldwide (Scherrer et al. 2004, Loncarevic et al. 2005, Rall et al. 2008). In a different study performed in Paraiba, the novel genes seb, sed, see and seh were not detected in staphylococci from bulk goat milk (Lyra et al. 2013).
The fact thatsecgene seems to be indeed the most frequent enterotoxin-encoding gene found in staphylococci from goat milk might be especially important for surveillance systems purposes, since enterotoxin $C$ should be investigated in human staphylococcal food poisoning outbreaks and cases caused by ingestion of goat milk and goat dairy products. On the other hand, $s e A$ has been shown to be the most frequent enterotox-in-encoding gene in $S$. aureus from bovine milk in Brazil (Rall et al. 2008).

Considering the gene sel, found in one positive isolate only (14.2\%), low frequencies of this gene has also been reported in $S$. aureus from goat milk in other countries (Scherrer et al. 2004, Rosec \& Gigaud2002).

No association of enterotoxin-encoding genes was observed amongst $S$. aureus in the present study, i.e., only isolates harboring a single gene were detected. This result is expected since only two genes were detected and the majority of the isolates was positive for one of them only $(\mathrm{sec})$. However, positive isolates harboring two or more genes have been reported in S. aureus from goat (Scherrer et al. 2004, Lyra et al. 2013) and bovine milk (Rall et al. 2008).

\section{CONCLUSIONS}

Staphylococcus aureus ausing mastitis in lactating goats can also harbor enterotoxin-encoding genes, especially sec, found amongst the majority of $S$. aureus positive isolates.

Investigation of enterotoxin $C$ should be considered in human staphylococcal food poisoning outbreaks caused by consumption of goat milk and dairy products by surveillance systems.

\section{REFERENCES}

Blaiotta G., Ercolini D., Pennacchia C., Fusco V., Casaburi A., Pepe O. \& Villani F. 2004. PCR detection of staphylococcal enterotoxin genes in Staphylococcus spp. strains isolated from meat and dairy products: evidence for new variants of seG and seI in S. aureus. J. Appl. Microbiol. 97(4):719-730.

Brasil 2010. Manual Integrado de Vigilância, Prevenção e Controle de Doenças Transmitidas por Alimentos. Secretaria de Vigilância Epidemiológica, Ministério da Saúde, Brasília, DF. Disponível em <http://portal. saude.gov.br>

Cremonesi P., Castiglioni B., Malferrari G., Biunno I., Vimercati C., Moroni P., Morandi S. \& Luzzana M. 2006. Improved method for rapid DNA extraction of mastitis pathogens directly from milk. J. Dairy Sci. 89(1):163169.

Jarraud S., Cozon G., Vandenesch F., Etienne M.B. \& Lina G. 1999. Involvement of enterotoxins $G$ and I in staphylococcal toxic shock syndrome and staphylococcal scarlet fever. J. Clin. Microbiol. 37(8):2446-2449.

Johnson W.M., Tyler S.D., Ewa E.P., Ashton F.E., Pollard D.R. \& Rozze K.R. 1991. Detection of genes for enterotoxins, exfoliative toxins, and toxic shock syndrome toxin 1 in Staphylococcus aureus by the polymerase chain reaction. J. Clin. Microbiol. 29(3):426-430.

Loncarevic S., Jorgensen H.J., Lovseth A., Mathisen T. \& Rorvik L.M. 2005. Diversity of Staphylococcus aureus enterotoxin types within single samples of raw milk and raw milk products. J. Appl. Microbiol. 98(2):344350 .

Lyra D.G., Sousa F.G., Borges M.F., Givisiez P.E., Queiroga R.C., Souza E.L., Gebreyes W.A. \& Oliveira C.J. 2013. Enterotoxin-emcoding genes in Staphylococcus spp. from bulk goat milk. Foodborne Pathog. Dis. 10(2):126130.

Mork T., Kvitle B., Mathisen T. \& Jorgensen H.J. 2010. Bacteriological and 
molecular investigations of Staphylococcus aureus in dairy goats. Vet. Microbiol. 141(134):134-141.

Nader Filho A., Ferreira L.M., Amaral L.A., Rossi Júnior O.D. \& Oliveira R.P. 2007. Produção de enterotoxinas e da toxina da síndrome do choque tóxico por cepas de Staphylococcus aureus isolados na mastite bovina. Arq. Bras. Med. Vet. Zootec. 59(5):1316-1218.

Rall V.L.M., Vieira F.P., Rall R., Vieitis R.L., Fernandes Jr A., Candeias J.M., Cardoso K.F. \& Araújo Jr J.P. 2008. PCR detection of staphylococcal enterotoxin genes in Staphylococcus aureus strain isolated from raw and pasteurized milk. Vet. Microbiol. 132(3/4):408-413.

Rosec J.P. \& Gigaud O. 2002. Staphylococcal enterotoxin genes of clas- sical and new types detected by PCR in France. Int. J. Food Microbiol. 77(1/2):61-70.

Sambrook J., Fritsch E.F. \& Maniatis T. 1989. Molecular Cloning: a laboratory manual. $2^{\text {nd }}$ ed. Cold Spring Harbor Press, New York.

Scherrer D., Corti S., Muehlher J.E., Zweifel C. \& Stephan R. 2004. Phenotypic and genotypic characteristics of Staphylococcus aureus isolates from raw bulk-tank samples of goat and sheep. Vet. Microbiol. 101(2):101107.

Silva E.R., Carmo L.S. \& Silva N. 2005. Detection of the enterotoxins A, B and C genes in Staphylococcus aureus from goat and bovine mastitis in Brazilian dairy herds. Vet. Microbiol. 106(1/2):103-107. 